\title{
Effect of dietary fish meal on the palatability and fatty acid composition of pork
}

\author{
Jarmo Valaja, Kaja Suomi, Timo AlaviuhKola and Irma Immonen \\ Valaja J., Suomi, K., Alaviuhrola, T. \& Immonen, I. 1992. Effect of dietary fish \\ meal on the palatability and fatty acid composition of pork. Agric. Sci. Finl. 1:21- \\ 26. (Agric. Res. Centre of Finland, Swine Res. Sta. SF-05840 Hyvinkää, Finland).
}

The effect of graded levels of dietary fish meal was studied with growing pigs in two trials. Test diets contained fish meal $0,2.7,6.5$ and $13 \%$ in trial 1 and $0,2,5$ and $10 \%$ in trial 2. In trial 2, diets containing 5 or $10 \%$ of fish meal were divided into four different treatments, where fish meal was withdrawn from the diet $7,5,3$ or 0 weeks before slaughter.

There were no significant differences in performance results between the treatments in trial 1 .

The contents of long chain polyunsaturated fatty acids C22:5 and C22:6 in the pork fat were analyzed in both trials and they increased linearly with increasing level of fish meal in the diets (trial 1 and 2$)(\mathrm{p}<0.001)$ and with length of fish meal feeding period (trial 2) $(\mathrm{p}<0.001)$.

In organoleptic analyses of fresh meat samples there were no statistical differences between the treatments in trial 1 . No off-flavours could be found from the fresh meat samples in trial 2. After a freezing period of $7-8$ months, the off-flavour of the meat increased linearly with increasing content of fish meal in the diet in trial $1(\mathrm{p}<0.001)$. In trial 2, distinctness of off-flavours increased also with the level of fish meal and with the length of fish meal feeding period.

Key words: pig, fish meal, off-flavour, fatty acid.

\section{Introduction}

Fish meal has long been an important protein supplement in Finland. Due to restrictions in soya bean import, commercial feed manufacturers had to increase the fish meal content in the mixtures up to $5-8 \%$. After a while, consumer complaints of offflavour in pork meat started to increase on the domestic market and in countries where Finnish pork was exported. Because of the great seasonal variation in pork consumption in Finland pork meat, especially ham, has to be frozen and stored for several months.

It is known that fish oil increases the risk of fishy taste in pork meat particularly after long storage (AgERHEM et al. 1984, PIKE and BARLOW 1977). In Sweden, $0.02 \%$ of fish oil was the recommended maximum level in the feeds of growing pigs. It was also found that the content of two long chain polyunsaturated fatty acids, $\mathrm{C} 22: 5$ and $\mathrm{C} 22: 6$, is a good indicator of off-flavours in pork fat (AGERHEM et al. 1984). For practical purposes, more information was still needed to find out how much standard quality fat-rich ( $8-12 \%$ crude fat) fish meal should be included in pig diet and what is the effect of withdrawal period on the off-flavour incidence. 


\section{Material and methods}

Feeding trial 1 was conducted with 112 Yorkshire and Landrace pigs. The pigs were assigned at random to four treatments. Two pigs were placed in each pen, the gilts and castrates being kept apart. Each diet was tested on seven pens of gilts and seven pens of castrates.

The diets of trial 1 contained $0,0.2,0.5$ or $1.0 \%$ of fish fat. Fish meal was added $0,2.7,6.5$ or $13.0 \%$, respectively, to complement the fish fat levels. The control diet contained soya bean meal as a protein source. In diet 4, all $20 \%$ soya bean meal was replaced by fish meal (Table 1).

The fish meal used in trial 1 was commercial type herring meal typically used in feed industry. It contained $70.5 \%$ of crude protein and $8.1 \%$ of ether extract. The long chain polyunsaturated fatty acid C22:5 and C22:6 contents of fish meal were 0.6 and $8.4 \%$ of total fatty acids, respectively. The trimethylamine content of the fish meal was 340 $\mathrm{mg} / 100 \mathrm{~g}$.

The four treatments recieved the same daily amount of protein and energy. Pigs were given 1.23.0 feed units/day from $25 \mathrm{~kg}$ live weight to slaughter at an average live weight of $100 \mathrm{~kg}$. Weight gain and feed consumption were registered during the experiment.

At slaughter, pork chop samples were collected for fatty acid and organoleptic analyses. Both analyses were conducted at the Finnish Meat Research Centre. The fatty acid (C22:5 and C22:6) content was analyzed with a Hewlett Packard 5890 gas chromatograph using the glass column NB-351 (Helium gas, detector temp. $270{ }^{\circ} \mathrm{C}$ and injector temp. $250^{\circ} \mathrm{C}$ ). The organoleptic analyses of the meat samples were conducted both in fresh state and after 7-8 months of frozen storage by a tested expert panel consisting of 8-10 experts for each analysis. The rating scale was: $0=$ no off-flavour, $1=$ slight offflavour, $2=$ medium off-flavour and $3=$ strong offflavour.

Trial 2 was conducted with 80 Yorkshire and Landrace pigs, which were divided into ten treatments of eight pigs. Eight pigs (four gilts and four castrates) were placed in the same pen. The experimental diets contained $0,2,5$ or $10 \%$ of fish meal. The long chain polyunsaturated fatty acid (C22:5 and C22:6) content of the diets was 0, 0.19, 0.49 or $0.97 \%$, respectively. The fish meal was commercial type and containted C22:5 and C22:6 fatty acids 0.8 and $14.0 \%$ of the total fatty acid content, respectively.

The ten treatments were fed at the same daily

Table 1. Composition of diets in trial 1.

\begin{tabular}{|c|c|c|c|c|}
\hline Diet & 1 & 2 & 3 & 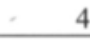 \\
\hline Barley, \% & 76.0 & 77.6 & 80.0 & 84.0 \\
\hline Fish meal, \% & - & 2.7 & 6.5 & 13.0 \\
\hline Soya bean meal, \% & 20.0 & 16.0 & 10.0 & - \\
\hline Mineral and vitamin, $\%^{1}$ & 3.0 & 3.0 & 3.0 & 3.0 \\
\hline Feed phosphate, $\%$ & 1.0 & 0.7 & 0.5 & - \\
\hline \multicolumn{5}{|c|}{ Chemical composition (calculated): } \\
\hline Feed unit $(\mathrm{FU} / \mathrm{kg})^{2}$ & 0.97 & 0.97 & 0.98 & 1.00 \\
\hline Digestible crude protein, $\%$ & 13.8 & 13.9 & 13.9 & 14.0 \\
\hline Lysine, $\%$ & 0.86 & 0.90 & 0.96 & 1.03 \\
\hline Fish fat, $\%$ & 0.0 & 0.2 & 0.5 & 1.0 \\
\hline \multicolumn{5}{|l|}{ Fish fatty acids } \\
\hline $\mathrm{C} 22: 5+\mathrm{C} 22: 6, \%$ & 0.0 & 0.020 & 0.047 & 0.095 \\
\hline
\end{tabular}

1. Vitamin E supplementation $30 \mathrm{mg} / \mathrm{kg}$ diet.

2. $\mathrm{FU}=0.7 \mathrm{~kg}$ starch equivalent. 
amount of energy and protein from $25 \mathrm{~kg}$ live weight to slaughter. Pigs were given 1.2-2.9 feed units/day. Four treatments were given the same diets from the beginning to slaughter $(0,2,5$ or $10 \%$ of fish meal $)$. At 5 and $10 \%$ fish meal levels there were three treatments in each level where fish meal was withdrawn from the diet 7,5 or 3 weeks before slaughter at 45,60 and $75 \mathrm{~kg}$ live weight, respectively (Table 2). All pens of eight animals were slaughtered at the same time. The live weight of the animals varied from 86.0 to $98.2 \mathrm{~kg}$ at slaughter.

At slaughter, pork chop samples were collected for

Table 2. Trial design (trial 2).

\begin{tabular}{lcc}
\hline Treatment & $\begin{array}{l}\text { Fish meal, } \\
\% \text { of diet }\end{array}$ & $\begin{array}{l}\text { Withdrawal period, } \\
\text { weeks before slaughter }\end{array}$ \\
\hline & & \\
1 & 0 & - \\
2 & 2 & - \\
3 & 5 & 7 \\
4 & 5 & 5 \\
5 & 5 & 3 \\
6 & 5 & - \\
7 & 10 & 7 \\
8 & 10 & 5 \\
9 & 10 & 3 \\
10 & 10 & - \\
\hline
\end{tabular}

fatty acid and organoleptic analyses. The fatty acid (C22:5 and C22:6) content was analyzed by the State Institute of Agricultural Chemistry. Pork chop samples were organoleptically evaluated both in fresh state and after six months of frozen storage at the Swine Research Station. The unprofessional test panel consisted of 14 members. A three point rating scale was used ( $1=$ worst score; 3 = best score).

The results of trial 1 were investigated using the analysis of variance with treatment and sex as factors. The results of each individual animal were used as an observation. The difference between treatments was tested with polynomial contrasts. Because only one replicate was used in each treatment in trial 2, the performance results could not be statistically analysed. The results of the fatty acid analysis in trial 2 were investigated with one-way analysis of variance and the difference between treatments was tested with polynomial contrasts.

\section{Results and discussion}

The main purpose of the trials was not the performance results. However, the results of trial 1 show clearly that fish meal can be replaced by soya bean meal for protein source in growing pigs without any negative effect on the performance of

Table 3. Performance and carcass quality of the pigs, polyunsaturated fatty acid (C22:5 and C22:6) content of the pork fat and organoleptic analysis of the meat samples. Means of 28 pigs per treatment are presented (Trial 1).

\begin{tabular}{|c|c|c|c|c|c|c|c|}
\hline \multirow[t]{2}{*}{ Treatment } & \multirow[t]{2}{*}{1} & \multirow[t]{2}{*}{2} & \multirow[t]{2}{*}{3} & \multirow[t]{2}{*}{4} & \multirow[t]{2}{*}{ SEM } & \multicolumn{2}{|c|}{$\begin{array}{c}\text { Statistical significance } \\
\text { of effect }\end{array}$} \\
\hline & & & & & & $\mathrm{L}$ & Q \\
\hline $\begin{array}{l}\text { Daily gain, g/d } \\
\text { Feed conversion }\end{array}$ & 860 & 879 & 877 & 883 & 14.49 & NS & NS \\
\hline efficiency, FU/kg & 2.66 & 2.58 & 2.60 & 2.61 & 0.04 & NS & NS \\
\hline $\begin{array}{l}\text { Meat in carcass, \% } \\
\text { Fatty acids }\end{array}$ & 50.1 & 50.7 & 50.1 & 49.8 & 0.44 & NS & NS \\
\hline $\begin{array}{l}\text { (C22:5 and C22:6), \% } \\
\text { Organoleptic analysis }\end{array}$ & 0.23 & 0.53 & 0.88 & 1.46 & 0.02 & $* * *$ & NS \\
\hline Fresh & 0.63 & 0.48 & 0.36 & 0.46 & 0.22 & NS & NS \\
\hline $7-8$ months frozen & 0.19 & 0.42 & 0.81 & 1.89 & 0.20 & $* * *$ & NS \\
\hline
\end{tabular}

$\mathrm{SEM}=$ Standard error of means; significance: $\mathrm{NS}=$ non-significant; ${ }^{* * *}(\mathrm{P}<0.001)$.

$\mathrm{L}, \mathrm{Q}=$ linear and quadratic effects of fish meal.

1. 0 -no off-flavour, 1=slight off-flavour, 2=medium off-flavour and 3=strong off-flavour. 
the animals (Table 3). Daily gain, feed conversion efficiency and carcass quality showed no significant differences between treatments. The trial confirms the earlier results of BARBER et al. (1981) and LYSO (1979). The tendency to a slightly better gain and feed conversion in fish meal groups could be due to better amino acid profile of fish meal compared to soya bean meal. This was also noticed by LYso (1979). The performance results of trial 2 are not presented, because they were not subjected to statistical testing.

There were no statistical differences between the treatments in the organoleptic analyses of fresh meat in trial 1 . However, the panel found some offflavour in individual meat samples of all treatments, but it could not be connected to the fish meal in the diet. In trial 2, no off-flavours were found in fresh meat samples. HvidSTEN and AsTRUP (1963) and AgERHEM et al. (1984) have shown a tendency to off-flavours in the taste of fresh pork when $9-12 \%$ of fish meal has been included in the diet.

The off-flavour in pork chops increased linearly after 7-8 months of frozen storage in trial 1 $(p<0.001)$ (Fig. 1). In trial 2, the incidence of offflavours increased after 6 months of frozen storage in groups where 5 or $10 \%$ fish meal was included in the diet (Fig. 3). This was also reported by HVidsTEN and Astrup (1963), Lyso (1979) and HeRTZMAN et al. (1988).

The organoleptic scores clearly correlated with

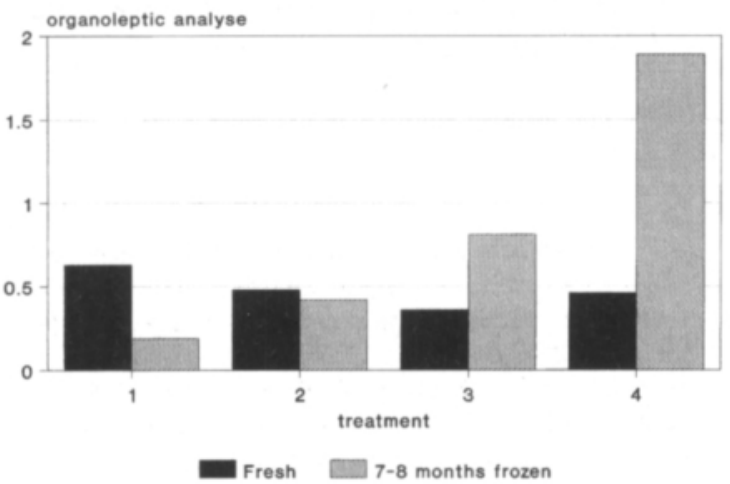

Fig. 1. Organoleptic scores of fresh and 7-8 months frozen stored pork chop samples (trial 2). the content of fish oil in the feed in the study of KIFER et al. (1971). In trial 1 this was true only when meat samples stored frozen for $7-8$ months were tasted $(r=0.59)$.

The contents of C22:5 and C22:6 fatty acids in pork fat increased linearly with increasing amount of fish meal (and fish oil or C22:5 and C22:6 fatty acids) in the feed (Fig. 2) $(\mathrm{p}<0.001)$. This was previously observed in experiment published by AGERHEM et al. (1984).

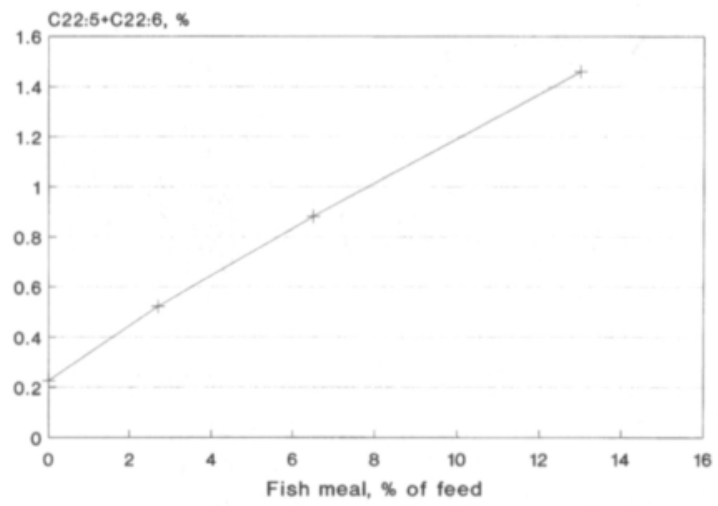

Fig. 2. Polyunsaturated fatty acid (C22:5 and C22:6) content of pork fat (trial 1).

Fish fat and especially long chain polyunsaturated fatty acids C22:5 and C22:6 are highly digestible in all animals. The apparent digestibility of fish fat for pig is over $90 \%$ (OPSTVEDT 1984) and apparent digestibility of $\mathrm{C} 22: 5$ and $\mathrm{C} 22: 6$ fatty acids in chicken $95 \%$ (OPSTVEDT 1973). Dietary fat is converted more efficiently to body fat compared to de novo fat synthesis from carbohydrates (BERSCHAUER 1986). Dietary long chain fatty acids are predominantly corporated to body fats and medium chain fatty acids are largely oxidized by the liver to $\mathrm{CO}_{2}$, acetate and ketone bodies (BERSCHAUER 1986). The deposition of digested C22:5 fatty acid is $78.9 \%$ and the deposition of $\mathrm{C} 22: 6$ is $8.8 \%$ for chicken, when the average deposition of lipids is 26.2\% (OPSTVEDT 1973).

The content of $\mathrm{C} 22: 5$ and $\mathrm{C} 22: 6$ fatty acids of the total fatty acids increased also linearly with the level 
of fish meal in the diet and with the length of the fish meal feeding period in trial 2 (Fig. 3) $(\mathrm{p}<0.001)$. HERTZMAN et. al. (1988) found also that the content of $\mathrm{C} 22: 6$ fatty acid in the pork fat increased linearly with the length of the fish meal feeding period. In trial 2, the content of C22:5 and C22:6 fatty acids in the carcass fat correlated positively with the fish oil content of the feed $(r=0.54)$ and with the length of

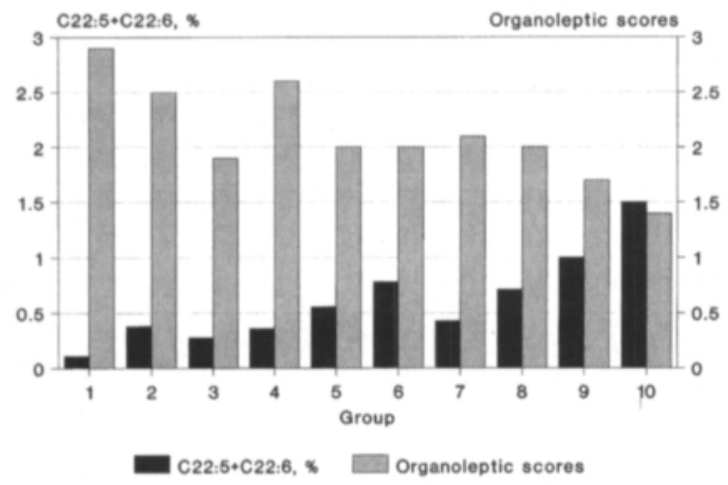

Fig. 3. Polyunsaturated fatty acid (C22:5 and C22:6) content of pork fat and organoleptic scores of 6 months frozen stored pork chop samples (rating: 1-3, 1=worst score; $3=$ best score) (trial 2).

the fish meal feeding period $(\mathrm{r}=0.67)$.

In trial 2, the contents of $\mathrm{C} 22: 5$ and $\mathrm{C} 22: 6$ fractions of the total fatty acids were less than $0.5 \%$ in all pigs fed without fish meal or with $2 \%$ of fish meal. At a $5 \%$ fish meal level, the $\mathrm{C} 22: 5$ and $\mathrm{C} 22: 6$ content of samples was less than $0.5 \%$ when fish meal was withdrawn from the diet 5 or 7 weeks before slaughter, at $10 \%$ fish meal level 7 weeks before slaughter. However, the organoleptic scores of these groups were slightly decreased compared to groups fed without or with $2 \%$ of fish meal.

In both trials, traces of $\mathrm{C} 22: 5$ and $\mathrm{C} 22: 6$ fatty acids were found in carcass fat in the groups not fed fish meal ( 0.11 and $0.32 \%$, respectively). It is possible that they originate from pre- and postweaning feed of the animals which contained fish meal. However, the results of the study reported by VALAJA (1991) showed that there were no differences in C22:5 and C22:6 fatty acid contents of pork fat in pigs fed with or without fish meal in the pre- and postweaning period.

It seems possible to set recommendations for use of fish meal concerning percentage in the feed as well as the length of the withdrawal period. The problem is the reasonably great variation between individuals, which makes it difficult for slaughterhouses or authorities to control the use of fish meal. Further, it is not known which part of $\mathrm{C} 22: 5$ and C22:6 fatty acids originates from meat meal and meat and bone meal used, and how much long chain polyunsaturated fatty acids the pig can produce from other essential fatty acids.

In conclusion, standard quality fish meal containing $8-10 \%$ of crude fat can be added to the diet of pigs up to $10 \%$ without any risk of fishy taste in the fresh meat. If the pork has to be stored frozen for several months the risk of off-flavours increases clearly. In all situations it is safe to restrict the fish meal content of the diet to under $2 \%$. The diet of feeder pigs up to $45 \mathrm{~kg}$ weight may contain fish meal up to $5 \%$ if a withdrawal period is used.

\section{References}

Agerhem, H., Berg, H., Kolar, K. \& Ohlander, I. 1984. Sensoriska respektive kemiska egenskaper hos kött och fett från svin utfodrade med foder innehållande olika mängder fiskmjöl. R-160-3563. Köttforsknings Institutet, Sweden.

Barber, R.S., Braude, R. \& Mitchell, M. 1981. Copper supplementation of isonitrogenous diets for growing pigs containing white-fish meal or soya bean meal as the protein supplement. Anim. Prod. 33: 81-86.

Barlow, S.M. \& PIKE, J.H. 1977. Die Bedeutung des Fettes im Fischmehl in der Futterung von Schweinen und Geflugel. Int. Assoc. Fish Meal Manuf. Tech. Bull. n:o 4.

Berschauer, F. 1986. Fats in diets for growing pigs. Pig News and Information 7(2): 153-158.

Hertzman, C., Göransson, L. \& Ruderus, H. 1988. Influence of fish meal, rape-seed and rape-seed meal in the feed on the fatty acid composition and storage stability of porcine body fat. Meat Science 23: 37-53.

Hvidsten, H. \& Astrup, H. 1963. The effect of vitamin E on the keeping quality and flavour of pork. Acta Agric. 
Scand. 13 (3): 259-270.

KIFER, R.R., SMITH, P. JR. \& YounG, E.P. 1971. Effect of dietary fish oil on the fatty acid composition and palatability of pork tissues. Biological Abstracts. 52 (21): 118655.

LYso, A. 1979. Ulik forstyrke til purger og galter foret med og uten sildemel og med og uten ekstra E-vitamintilskudd. Meld. Norges Landbrukshogskole. 58 (23): 1-17.

OPSTVEDT, J. 1973. Influence of residual lipids on nutritive value of fish meal. V. Digestion and deposition of marine fatty acids in chickens. Acta Agr. Scand 23: 218224.

- 1984. Fish Fats. In: Wiseman, J. (eds.). Fats in animal nutrition. p. 53-82. Wiseman, J. Butterworths, London.

VALAJA, J. 1991. Kalajauho porsasrehussa ei nosta kalanrasvahappopitoisuutta. Lihantuottaja 3: 28.
Manuscript received June 1991

Jarmo Valaja

Kaija Suomi

Timo Alaviuhkola

Agricultural Research Centre of Finland

Swine Research Station

SF-05840 Hyvinkää, Finland

Irma Immonen

Agricultural Research Centre of Finland

Swine Research Station

SF-05840 Hyvinkää, Finland

Present adress:

Kruununkatu 64

SF-05840 Hyvinkåä, Finland

\title{
SELOSTUS
}

\section{Kalajauhon vaikutus sianlihan makuun ja rasvahappokoostumukseen}

\author{
Jarmo Valaja, Kaija Suomi, Timo Alaviuhkola ja Irma Immonen \\ Maatalouden tutkimuskeskus
}

Kaksiosaisessa tutkimuksessa selvitettiin dieetin erilaisten kalajauhomäärien vaikutusta lihasikojen tuotantotuloksiin sekă lihan rasvahappokoostumukseen ja makuun. Toisessa osassa selvitettiin myös, kuinka kalajauhon poisjättäminen rehusta eri aikoina ennen teurastusta vaikuttaa sian silavan rasvahappokoostumukseen ja makuun. Ensimmäisessă kokeessa rehut sisălsivät kalajauhoa $0,2.7,6.5$ ja $13.0 \%$ ja koeryhmät saivat samaa rehuseosta koko kokeen ajan. Toisessa kokeessa rehuissa oli kalajauhoa $0,2,5$ ja $10 \%$. Osa koeryhmistä sai kalajauhopitoista rehua koko kokeen ajan ja osalla ryhmistä kalajauhon käyttö lopetettiin 7, 5 tai 3 viikkoa ennen teurastusta.

Kokeissa ei havaittu merkitseviă eroja tuotantotuloksissa eri ryhmien vălillä. Rasvahappoanalyyseissă tutkittiin silavan kalarasvahappojen C22:5 ja C22:6 osuutta kokonaisrasvahapoista. Ensimmäisessä kokeessa ko. rasvahappojen pitoisuus silavassa nousi suoraviivaisesti, kun rehun kalajauhopitoisuus nousi $(\mathrm{p}<0.001)$. Toisessa kokeessa silavan C22:5- ja C22:6-rasvahappojen pitoisuus oli sitä alhaisempi mitä aikaisemmin ennen teurastusta kalajauhon käyttö lopetettiin. Kaksi prosenttia kalajauhoa saaneiden eläinten silavan $\mathrm{C} 22: 5$ - ja C22:6-rasvahappopitoisuus ei ylittänyt $0.5 \%$ rajaa kokeessa 2 .

Tuoreissa lihanäytteisså ei varsinaista kalanmakua esiintynyt. Puolen vuoden tai 7-8 kuukauden pakastuksen jälkeen lihan makuvirheet lisääntyivät, kun rehu sisälsi yli $5 \%$ kalajauhoa. Mită pidemmän aikaa eläimet saivat kalajauhoa sită selvemmin makuvirheet ilmenivăt. Kahden prosentin kalajauhomäărä ei aiheuttanut kalanmakua lihaan pakastussăilytyksen jälkeen.

Johtopäätöksenä kokeista voidaan sanoa, että tuoreessa sianlihassa ei ilmene kalanmakua, vaikka dieetissä on kalajauhoa jopa $10 \%$. Pakastuksen jälkeen kalajauhoa syöneiden eläinten lihassa makuvirheiden määră lisăäntyi selvästi. Kaikissa tilanteissa turvallista olisi kăyttăä kalajauhoa alle 2 \% lihasikojen dieeteissä. Alle 45 kiloisten lihasikojen rehu voi sisältää kalajauhoa $5 \%$, jos loppukasvatusrehu ei sisăllä kalajauhoa. 